\title{
KRAS NM_004985.3:c.34_35delGGinsAT
}

National Cancer Institute

\section{Source}

National Cancer Institute. KRAS NM 004985.3:C.34 35delGGinsAT. NCI Thesaurus. Code C98379.

A complex substitution where the nucleotide sequence at positions 34 through 35 of the coding sequence of the KRAS gene has changed from guanine-guanine to adeninethymine. 